\title{
SIX-MONTH EVALUATION OF ART ONE-SURFACE RESTORATIONS IN A COMMUNITY WITH HIGH CARIES EXPERIENCE IN BRAZIL
}

\author{
AVALIAÇÃO DE SEIS MESES DE RESTAURAÇÕES ART DE CLASSE I \\ EM UMA COMUNIDADE DE ALTA EXPERIÊNCIA DE CÁRIE NO BRASIL
}

\author{
Eduardo BRESCIANI ${ }^{1}$, Wendell Lima de CARVALHO ${ }^{2}$, Lúcia Coelho Garcia PEREIRA ${ }^{3}$ \\ Terezinha de Jesus Esteves BARATA ${ }^{1}$, Franklin GARCÍA-GODOY ${ }^{4}$, Maria Fidela de Lima NAVARRO ${ }^{5}$
}

1- DDS, MSc, Graduate Student (Doctor degree), Department of Dental Materials, Endodontics and Operative Dentistry, Bauru Dental School USP, Brazil.

2- DDS, Fellow of Department of Dental Materials, Endodontics and Operative Dentistry, Bauru Dental School - USP, Brazil.

3- DDS, MSc, PhD, Assistant Professor, Departament of Dentistry, Anápolis Dental School, Brazil.

4- DDS, MSc, PhD, Associate Professor, Department of Restorative Dentistry, College of Dental Medicine, Nova Southeastern University, USA.

5- DDS, PhD, Professor, Department of Dental Materials, Endodontics and Operative Dentistry, Bauru Dental School - USP, Brazil.

Corresponding address: Dr. Maria Fidela de Lima Navarro, Department of Dental Materials, Endodontics and Operative Dentistry, Bauru Dental School - USP, Al. Octávio Pinheiro Brizolla, 9-75, CEP: 17012-101, Brazil. Fone: 5514 3235-8200. Fax: e-mail: mflnavar@usp.br

Received: July 30, 2004 - Modification: September 02, 2004 - Accepted: October 07, 2004

\begin{abstract}
$T$

he aim of this study to evaluate the success rate in one-surface ART restorations placed in permanent molars using a glass ionomer cement especially developed for ART in a community with high caries experience; to evaluate the operator influence on its success, postoperative sensitivity and technique acceptance by patients. Prior to placement of the restorations, the Gingival Bleeding Index, Visible Plaque Index, DMFT, dmft indices and treatment needed were assessed. One hundred and fifty five one-surface restorations were placed in permanent molars of school children, according to the WHO ART manual, 1997. After 6 months, the success rate was verified clinically and by slides. At baseline, the mean DMFT was $2.56( \pm 1.08)$ and the mean dmft, $2.53( \pm 2.33)$. Operators A and B have placed 102 and 53 ART restorations respectively. The mean time of placement was 16 minutes and 25 seconds to operator A and 14 minutes and 43 seconds to operator B. At 6-month follow up, 152 ART restorations were evaluated and $97.3 \%$ were assessed to be successful. Two restorations were excluded from the sample because the ART restorations were replaced by amalgam fillings. Only 4 restorations have failed, in which 2 due to caries, 1 due to fistula presence and the other because the restoration was lost. Four patients reported postoperative sensitivity. At this study period, ART treatment seems to be suitable for its purpose. Further evaluations are necessary to the new glass ionomer cements especially developed for ART technique provided good results at 6-month follow up in a community with high DMFT and dmft indices. The success rate for one-surface cavities in permanent molars was $97.3 \%$, and the studied indices seemed to have no influence in this early evolution period.

Uniterms: Dental caries; Glass ionomer cements; Clinical evaluation.
\end{abstract}

\section{RESUMO}

objetivo deste estudo foi avaliar o índice de sucesso de restaurações de cavidade de classe I, realizadas em molares permanentes, utilizando-se a técnica do ART e um cimento de ionômero de vidro desenvolvido especialmente para a técnica, em uma comunidade de alto risco à cárie; avaliar a influência do operador no sucesso da técnica e avaliar a sensibilidade pós-operatória e a aceitação da técnica por parte dos pacientes. Antes da realização do tratamento verificou-se o índice de placa visível e o índice de sangramento gengival, CPOD, ceo-d e necessidade de tratamento. Um total de 155 restaurações de uma superfície foram realizadas em molares permanentes de escolares, de acordo com o manual de ART da OMS. Após 6 meses, realizou-se o acompanhamento clínico e por diapositivos. Inicialmente, o CPOD foi de 2,56 $( \pm 1,08)$ e o ceod de $2,53( \pm 2,33)$. Os operadores A e B realizaram 102 e 53 restaurações de ART respectivamente. O tempo médio para o tratamento foi de 16 minutos e 25 segundos para A e 14 minutos e 43 segundos para B. Aos seis meses. 152 restaurações foram avaliadas e 97,3\% consideradas sucesso. Duas restaurações foram excluídas da amostra pois foram substituídas por amálgama. Somente 4 restaurações falharam, duas por recidiva de cárie, 1 por presença de fistula e a última por perda da restauração. Quatro pacientes relataram sensibilidade pós-operatória. O tratamento ART cumpriu seus objetivos no período analisado. Avaliações futuras são necessárias, especialmente para os cimentos de ionômero de vidro de alta viscosidade, devido aos bons resultados nesta comunidade de alto índice de cárie. O índice de sucesso foi de 97,3\% e os índices de cárie parecem não influenciar no sucesso do tratamento.

Unitermos: Cárie dentária; Cimentos de ionômero de vidro; Avaliação clínica. 


\section{INTRODUCTION}

According to the $\mathrm{WHO}^{25}$, dental caries and gingival disease are two of the most widespread diseases, and their prevention is based on good oral hygiene habits, use of fluorides and prudent diet. In developed countries the level of these diseases has dramatically decreased but it is still a problem in developing countries, where some communities have no oral care or cannot afford it. The equipments and instruments used to provide dental treatment are very expensive and electricity is required to run these equipments ${ }^{27}$. Consequently, dental caries go untreated and further extraction is almost always needed. In Brazil, 70.3\% of the extractions are related to caries disease or its sequels, confirming the high correlation between extraction and caries disease $^{3}$.

Regarding the population's difficulty to afford conventional dental treatment and because of the lack of expensive dental equipments in developing countries, Smith, et al..$^{19}(1990)$ tested and compared three kinds of restorations: amalgam, miracle mix and glass ionomer cements with amalgam powder. In the two latter, the cavities were prepared only with hand instruments. Significantly better results were observed with amalgam restorations than with the other two kinds of restorations ${ }^{19}$.

A new approach based on minimal intervention was pioneered in Tanzania in mid 1980s as part of an oral health program. In 1994, this technique called Atraumatic Restorative Treatment was recognized and endorsed by $\mathrm{WHO}^{25,26,27}$ in order to improve such situations. This new technique is based on caries tissue excavation with hand instruments such as spoon excavators, followed by restoring the cavity and sealing adjacent fissures with an adhesive material, a glass ionomer cement ${ }^{10}$. The advantages include the following: anesthesia and electrically driven equipment are not required ${ }^{9,10}$, removal of only decalcified tissue, painless technique, chemical adhesion of restorative material, fluoride release, low cost and combination of preventive and curative treatment in one procedure ${ }^{9}$. As limitations, Frencken, et al. ${ }^{9}$, (1996) reported: lack of long-term survival rates, low mechanical properties of glass ionomer cements, the misapprehension that ART can be performed easily, hand fatigue and some clinical limitations ${ }^{10}$ as pain history, pulp exposure and presence of fistula.

Many studies show good results at short-term period. Success rates of $93 \%, 83 \%$ and $71 \%$ at 1,2 and 3 years consequently to permanent teeth restorations are shown in the literature ${ }^{11}$. Some other studies reported good results using a glass ionomer cement classified as restorative type $e^{6,7,14,15,18}$. The success scores for one-year follow-up range from $76.3 \%{ }^{14}$ to $93.4 \%{ }^{7}$. At 3 -year recalls, the success rates ranged from $59 \%{ }^{14}$ to $85.3 \%,{ }^{8}$ and at 6 -year recalls the success of one-surface ART was $67 \%$. The DMFT of the population where these studies were carried out ranged from $1.1^{7}$ to $1.5^{18}$, which is very low, since the studies were carried out in populations with an average age over 12 years old.

Frencken, et al. ${ }^{6}(1998)$ and Mickenautsch, et al. ${ }^{16}(1999)$ reported better ART results using glass ionomer cements especially developed for this technique (Fuji IX and KetacMolar). The success was $98.6 \%, 93.8 \%$ and $88.3 \%$ after one, two and three years, respectively, in the first study, and 93.5\% at one-year recalls in the second study. The DMFT index in these studies ranged from $0.69^{6}$ to $1.1^{16}$.

While the cited studies were performed in communities with low DMFT and dmft indices, the literature is poor regarding to ART in areas with high DMFT and dmft indices. The present study aimed at evaluating the success rate of one-surface ART restorations in permanent teeth, using a glass ionomer cement especially designed for ART in a community with high caries experience, as well as differences between operators, postoperative sensitivity, treatment acceptance and treatment time.

\section{MATERIALAND METHODS}

The study was carried out in 4 public schools from suburban areas of Bauru, Brazil, during the period of June to August 2000. A total of 155 class I fillings were placed in 96 students aged 7 to 12 years old. Inclusion criteria of the study were presence of one or more cavities involving dentin and opening large enough to allow excavation with a small excavator. Exclusion criteria were pulp exposure, pain history and presence of fistula. A maximum of four restorations was allowed for each patient.

Prior to onset of treatment, a baseline examination was conducted. Visible Plaque Index (VPI), Gingival Bleeding Index $(\mathrm{GBI})^{1}$, DMFT, dmft Indices and caries treatment needs based on WHO criteria ${ }^{27}$ were assessed. To determine VPI, every tooth from the right side was evaluated. Concerning to GPI, every first permanent molar, the maxillary right central incisor and the mandibular left central incisor were evaluated. From each tooth, three different areas were observed, two buccal and one lingual surfaces. At buccal surface, the medial and central points of its cervical portion were evaluated while at lingual surface, just a central point of its cervical portion was assessed. If visible plaque or bleeding at the first ten seconds after probing were observed, a score 1 was written down. Score 0 indicated no plaque or bleeding presence. When the tooth was not present in the oral cavity or it was impossible to exam, a score 9 was written down. This method was chosen by its facility mainly to be executed and to clarify patients about their oral conditions.

Patients were submitted to treatment only after their parents provided a written consent and after approval from the local Ethics Committee.

The patients were fit in a proper position to the operator on a table with a cushioned headrest attached for their comfort. No electrically driven equipment and no anesthesia were used. Two trained operators used to the ART technique and to its steps performed the restorations. Operator A filled 102 teeth and operator B, 53 teeth. Ninety-seven out of 155 were mandibular permanent molars and the other 58 were maxillary molars (Table 1 ).

The tooth was isolated with cotton rolls to promote a dry environment. The tooth surface was cleaned with a wet 
cotton pellet, removing debris and plaque, thus improving visibility. If the cavity entrance was small, a dental hatchet was used to break off unsupported enamel and create an opening large enough for the small excavator to enter. Next, caries removal was made with spoon excavators, taking care to clean thoroughly the dentin-enamel junction before removing caries from the floor of the cavity. These steps limited any pain caused from cavity cleaning to just a few moments at the end of cavity preparation. Thin unsupported enamel was broken away using a hatchet. The prepared cavity was washed with a wet cotton pellet. A calcium hydroxide paste was applied if the cavity was very deep. A cotton pellet saturated with Ketac-Molar mixing liquid applied for 10 seconds was used for cavity conditioning. Then, the conditioned surfaces were washed several times with wet cotton pellets and dried with dry cotton pellets. Ketac-Molar was mixed according to the manufacturer's instructions and inserted into the cavity and the cavity slightly overfilled. Adjacent pits and fissures were sealed. After insertion, a gloved finger slightly pressed on the top of the restoration in order to avoid inclusion of air bubbles, to overflow any excess material and to provide a smooth restoration surface. Vaseline was used to coat the gloved finger to prevent the glass ionomer from sticking to the glove. Bite was checked with articulating paper and adjusted if necessary. To prevent the restoration from soaking and drying out, a layer of varnish (Copalite, Cooley \& Cooley) was used to cover the restoration. Patients were instructed not to eat for at least one hour. Every restoration was photographed at baseline (after excavation and after filled) and at the 6-month follow up (Figures. 2, 3 and 4)

The clinical evaluation was done in a period of 6 months clinically and by slides. The criteria used are present in Figure $1^{11}$, and scores 0,1 and 7 mean success, scores 2, 3, 4 and 8 failure and scores 5, 6 and 9 exclusion of the restoration from the sample. The intra-examiner reliability was 0.92 .

The chi-square test $(\mathrm{p}<0.05)$ was used to verify the influence of operator on the success of the restorations.

\section{RESULTS}

Regarding the GBI and to VPI, the mean values and standard deviation were $22.24 \% \pm 15.61$ and $61.18 \% \pm 19.25$, respectively. No correlation was observed between GBI and VPI (Pearson, $\mathrm{p}=0.0000685$ ). The mean DMFT was $2.56 \pm$ 1.08 and the mean dmft was $2.53 \pm 2.33$.

Sample distribution according to operator and its position in the arch (maxillary or mandibular) is shown in Table 1. It can be seen that operator A has placed two times the number of ART restorations provided by operator $\mathrm{B}$, instead of treating almost the same number of patients. Mandibular molars were more filled, 1.67 more times than maxillary molars. The mean time of restoration placement for operator A was 16 minutes and 25 seconds, while operator B has placed ART restorations in a mean time of 14 minutes

TABLE 1- Sample distribution of the ART restorations according to operator and to its position in upper or lower arch

\begin{tabular}{l|c|c|c}
\hline Operator & $\begin{array}{l}\text { Upper molar } \\
\text { Restoration }\end{array}$ & $\begin{array}{c}\text { Lower molar } \\
\text { Restoration }\end{array}$ & TOTAL \\
\hline OPERATORA & 39 & 63 & 102 \\
OPERATOR B & 19 & 34 & 53 \\
TOTAL & 58 & 97 & 155 \\
\hline
\end{tabular}

\begin{tabular}{|c|c|}
\hline SCORE & CRITERIA \\
\hline 0 & Present, good \\
\hline 1 & $\begin{array}{l}\text { Present, slight marginal defect for whatever reason, at any one place which is less than } 0.5 \mathrm{~mm} \text { in } \\
\text { depth: no repair is needed }\end{array}$ \\
\hline 2 & $\begin{array}{l}\text { Present, marginal defect for whatever reason, at any one place which is deeper than } 0.5 \mathrm{~mm} \text {, but less } \\
\text { than } 1.0 \mathrm{~mm} \text { : repair is needed }\end{array}$ \\
\hline 3 & Present, gross defect of more than $1.0 \mathrm{~mm}$ in depth: repair is needed \\
\hline 4 & Not present, restoration has (almost) completely disappeared: treatment is needed \\
\hline 5 & Not present, other restorative treatment has been performed \\
\hline 6 & Not present, tooth has been extracted \\
\hline 7 & $\begin{array}{l}\text { Present, wear and tear gradually over larger parts of the restoration but is less than } 0.5 \mathrm{~mm} \text { at the } \\
\text { deepest point: no repair is needed }\end{array}$ \\
\hline 8 & $\begin{array}{l}\text { Present, wear and tear gradually over larger parts of the restoration which is deeper than } 0.5 \mathrm{~mm} \text { : repair } \\
\text { is needed }\end{array}$ \\
\hline 9 & Unable to diagnose \\
\hline
\end{tabular}

FIGURE 1- Clinical criteria used to evaluate ART restorations 
and 43 seconds. The technique was well accepted by the patients.

The success rate can be seen in Table 2. A total of 152 restorations were evaluated at the 6-month follow up. Two patients with 3 restorations have moved to other cities and quit the study. Two patients had their ART fillings replaced by amalgam restorations (score 5) and thus were excluded from sample. They were asked the reason for changing ART fillings and they answered they had their ART changed just because they had got free dental treatment at public health and the dentist decided to change. They reported no pain. Four out of 150 presented a failure score (2.7\%). Operator A has placed one of these failed restorations, while operator $\mathrm{B}$ has placed the other 3 ones. Two of them were scored as 3 , needing replacement due to caries (Figures 5 to 7). One patient reported that she went to a dentist to remove the ART filling because of postoperative pain. The dentist removed the ART filling and performed no additional treatment, and it was scored as 4 . The last failed ART restoration was due to presence of fistula . This patient reported pain at the night of its placement and endodontic treatment was then provided. Only 4 patients reported postoperative sensitivity (2.7\%), 2 of which reported that it

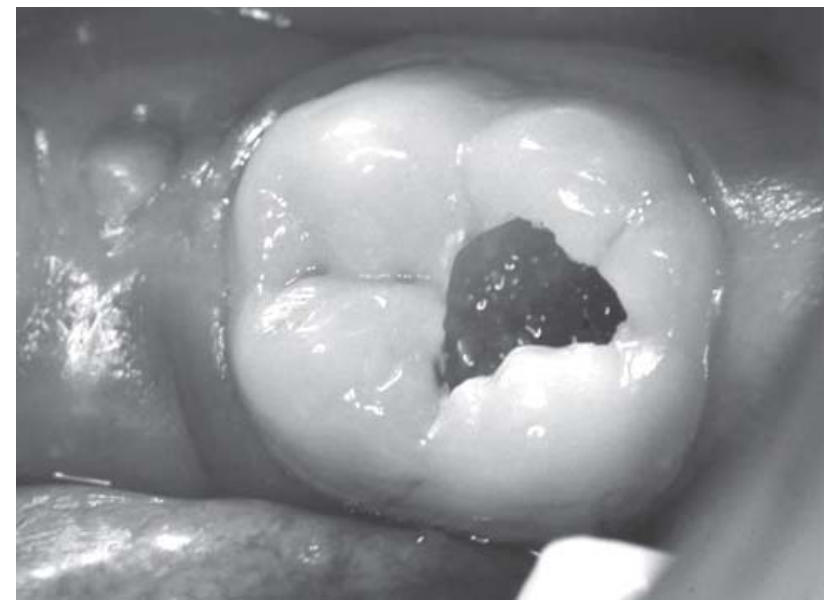

Figure 2- Cavity prepared, just after caries excavations and cavity cleaning

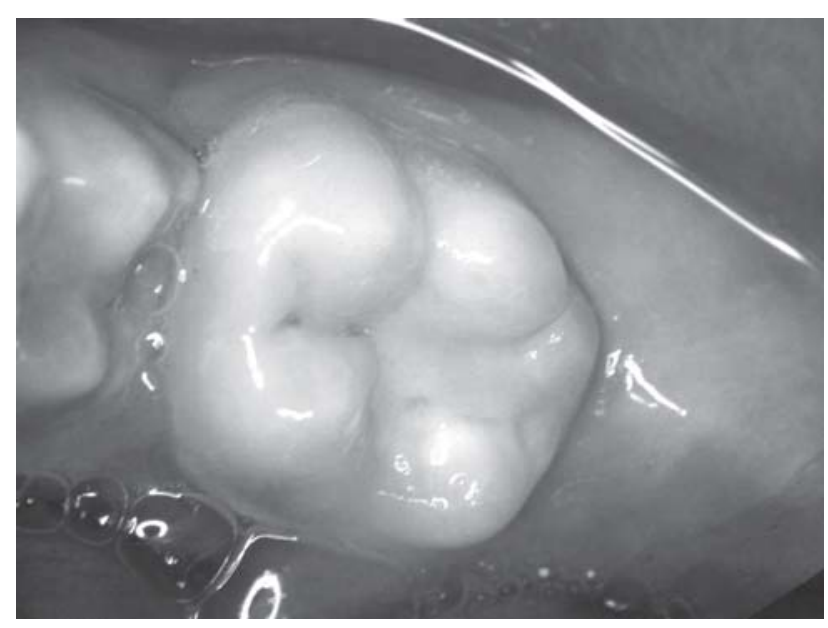

Figure 4- Control after six-month took just a few days and then the symptoms disappeared, while the other two got a failure score to their restorations. To verify if the operator had influence on the success of the restoration, the association test (Fisher, $\mathrm{p}=0.1178$ ) was performed and no statistical difference was found.

\section{DISCUSSION}

According to Frencken, et al. ${ }^{9}$ (1996), the misapprehension that ART can be performed easily and the apparent lack of sophistication are the two main limitations for professionals to assure this technique. The study performed by Souza, et al. ${ }^{20}$ (2003), showed lower results than the present, probably due to the lack of operator training. At the present study, special attention was paid to properly cleaning the dentinoenamel junction and adequately handling the material.

An important understanding is that the ART technique has a definitive place in modern clinical practice ${ }^{4}$ and offers an opportunity for restorative dental treatment under field conditions where electricity is not available $e^{9,10,17,27}$. Another reason is that ART promotes better dental conditions where

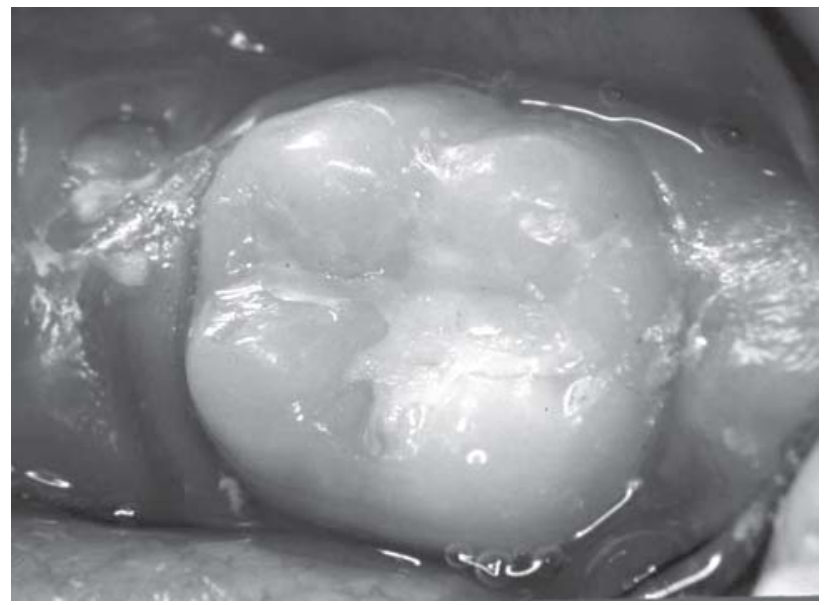

Figure 3- Restoration placed, at baseline

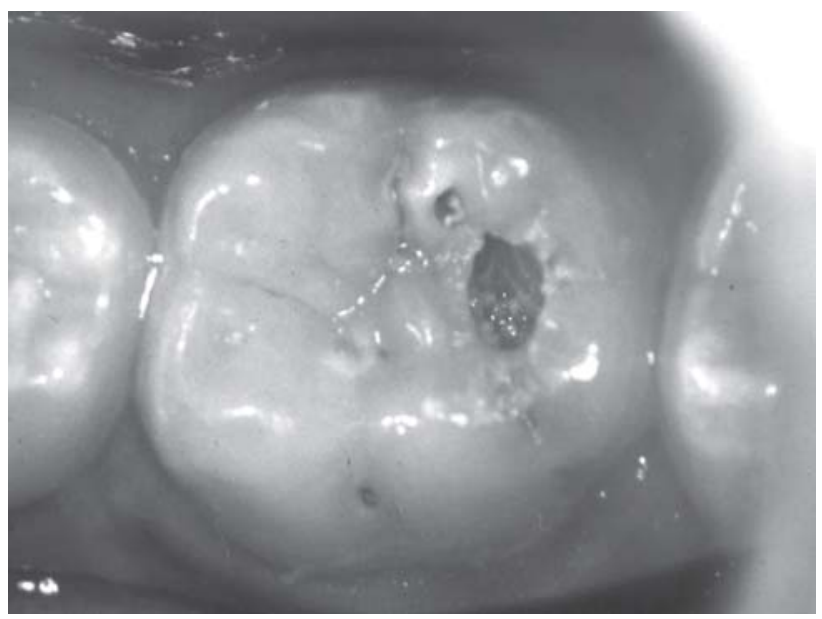

Figure 5- Cavity prepared, just after caries excavations and cavity cleaning 
it is implemented, reducing the number of extractions and raising the number of restored teeth ${ }^{16}$.

The success rate with the ART technique is progressively decreasing with time, mainly for conventional type II glass ionomer cements $s^{6,9,11,18}$. When using a glass ionomer cement developed for the ART technique (Fuji IX), better results were observed, ranging from 98.6 to $88.3 \%$ in 1 to 3 years $^{6}$. These new materials have their mechanical and physical properties improved ${ }^{5}$. This study also used improved GIC but the scores observed were not so good, probably because of the high caries experience of the patients.

The other cited studies were performed in areas where low DMFT and dmft indices were observed, so the failure was more related to the material properties and to the lack of retention in the cavity. In the present study, the DMFT and dmft indices were 2.56 and 2.53 respectively, very high in comparison with previous studies in which these indices ranged from 0.69 to 1.1. The Visible Plaque Index was not used in previous works but it could also interfere with the ART performance and the failure scores were mainly related to loss of restoration and the need of replacement due to secondary caries. When scores 5 and 6 , related to replacement of the restoration by other treatment or tooth extraction were observed, the restorations were excluded from the sample. This decision was taken in order to not under or overestimate the results.

The results of this study (97.3\% of success) after 6 months are similar to one-year follow-up studies, which range from $93.5 \%{ }^{12}$ to $98.6 \%{ }^{6}$. It can be expected that this performance will not decrease very much as it used to happen in early studies, because the GIC used is of high

TABLE 2- Success rate of 150 ART restorations after 6 months, according to operator

\begin{tabular}{l|lll}
\hline Operator & SUCCESS & FAILLURE & TOTAL \\
\hline OPERATORA & $99(99 \%)$ & $1(1 \%)$ & 100 \\
OPERATOR B & $47(94 \%)$ & $3(6 \%)$ & 50 \\
TOTAL & $146(97.3 \%)$ & $4(2.7 \%)$ & 150 \\
\hline
\end{tabular}

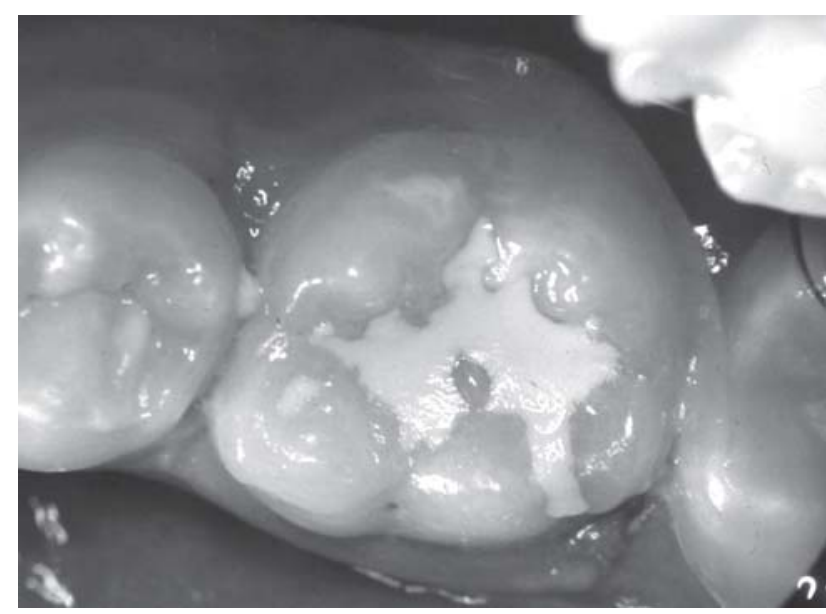

Figure 6- Restoration placed, at baseline density, but it is not known how these high indices of caries will influence the success in a more spaced period, which will be seen in future recalls.

One of the difficulties in the present study was observed when the cavity entrance was not large enough to allow proper cleaning of the cavity. The smaller excavator entered in the cavity, but movements with this excavator inside it in order to clean the cavity were limited. In one of the restorations, the entrance was so small that the cleaning certainly was not done properly and the tooth after six months required endodontic treatment, despite the apparent aspect of good sealing of the restoration (Figs 8, 9, 10 and 11).

Operator has been discussed at the literature as another variant in ART treatment ${ }^{7}$, because if better cavity cleaning and better restoration placement were provided by one operator, different results would be expected from different operators. In the present study the success rates ranged from 99\% to 94\% according to the operator and there have been no significant differences; the calibration training before starting this study led to this result.

Postoperative sensitivity has been related to the acid conditioning exposure time and proximity with the pulp ${ }^{7}$. In this study, the conditioning time was 10 seconds and sensitivity was associated with poor cleaning of the cavity or to the depth of the cavity, since in young patients even shallow cavities can have the cavity floor very close to the pulp because of the great volume of the pulp chamber. In two failed restorations, postoperative sensitivity was present. In one of them, the small opening of the cavity interfered with the proper cleaning of the cavity. In the other , the postoperative sensitivity occurred probably because the cavity was near to the pulp and it was not clinically detected, since no X-ray was used and it is impossible to make a precise diagnostic using only clinical examination.

Time is an important aspect of this technique and the literature shows longer periods $s^{6,7,9,14}$ than observed in this work besides the fact that in this study, all cavities were photographed after cavity preparation and after completion of the restoration. All procedures were done with auxiliary staff, which made the procedure more efficient.

The results of this study are in agreement with the

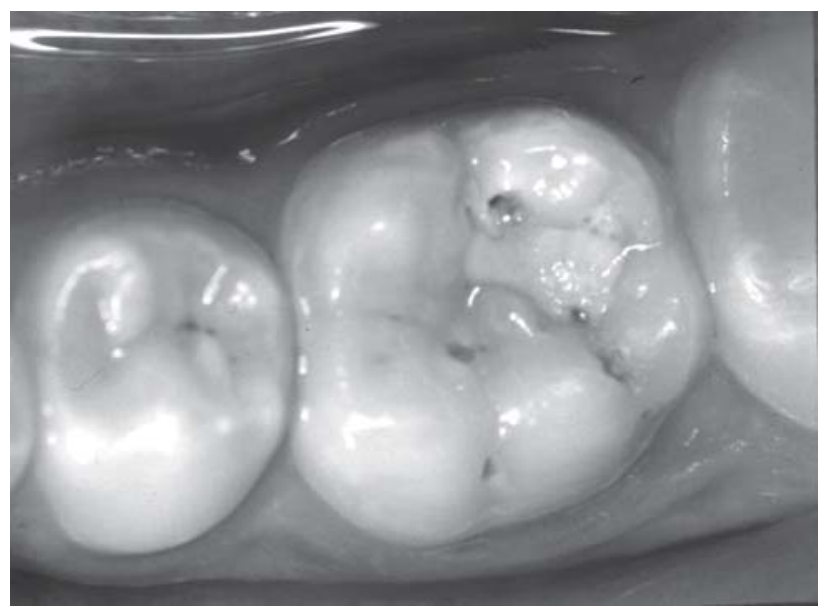

Figure 7- Failure due to secondary caries at 6-month recall 
literature ${ }^{6,7,8,14}$ regarding the good acceptance of this technique, and is related to the fact that no anesthesia is necessary, the working time is fast and it is a pain-free technique.

Despite the good results of ART, it is uncertain that glass ionomer will effectively bond to enamel and dentin ${ }^{5,13,22}$ and its power to arrest residual caries under restoration is not well proven ${ }^{21,23,24}$. Under these circumstances, bacterial infection may present a continuous growing and could cause ART restoration failures².

The ART restoration does not replace the conventional restorations, but it is an alternative for special patients or for treatment of populations living in areas without dental offices.

It is important to point out that preventive education of the population that will receive the ART treatment is always required and consists in one of the most important factors to be controlled for the success of this technique.

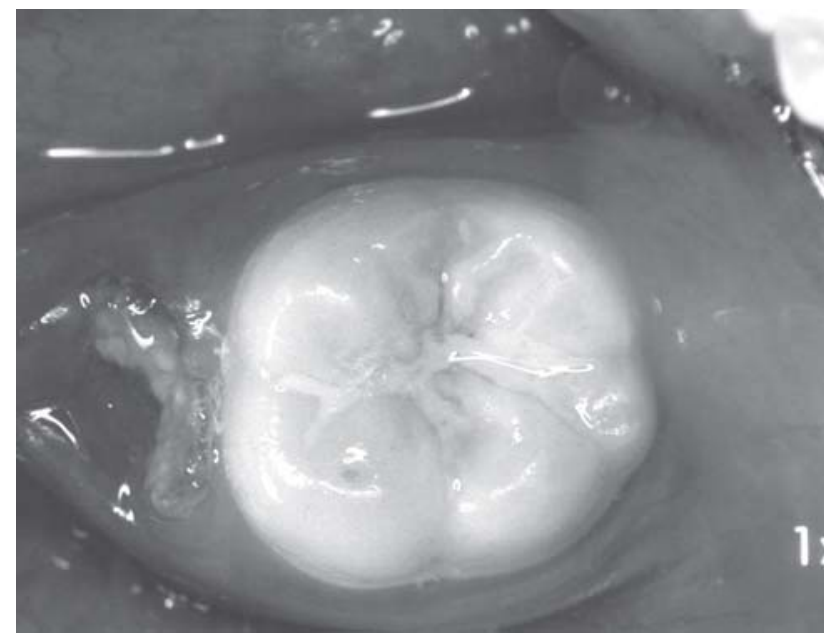

Figure 8- Small cavity entrance, filled at baseline

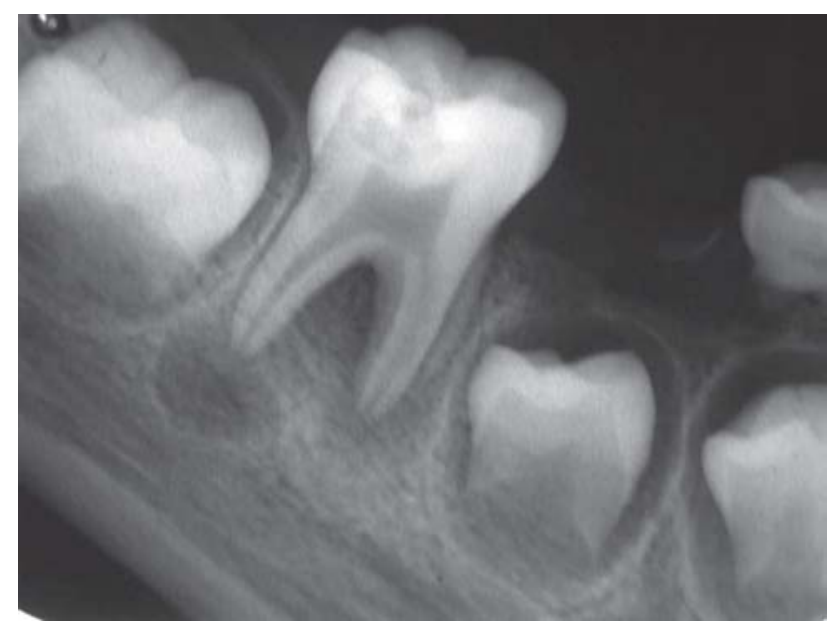

Figure $10-X$ ray showing small cavity but caries spreading at dentin-enamel junction

\section{CONCLUSION}

At this analyzed period, ART treatment seems to be suitable for its purpose. Further evaluations are necessary for this study, provided good results at 6-month follow-up in a community high caries experience. The success rate after 6 months for one-surface cavities in permanent molars was $97.3 \%$, and the studied indices seemed to have no influence in this early evaluation period.

\section{REFERENCES}

1- Ainamo J, Bay I. Problems and proposals for recording gingivitis and plaque. Int Dent J. 1975;25:229-35.

2- Anusavice KJ. Does ART have a place in preservative dentistry? Community Dent Oral Epidemiol. 1999;27:442-8.

3- Caldas AF, Marcenes W, Sheiham A. Reasons for tooth extraction in a Brazilian population. Int Dent J. 2000;50:267-73.

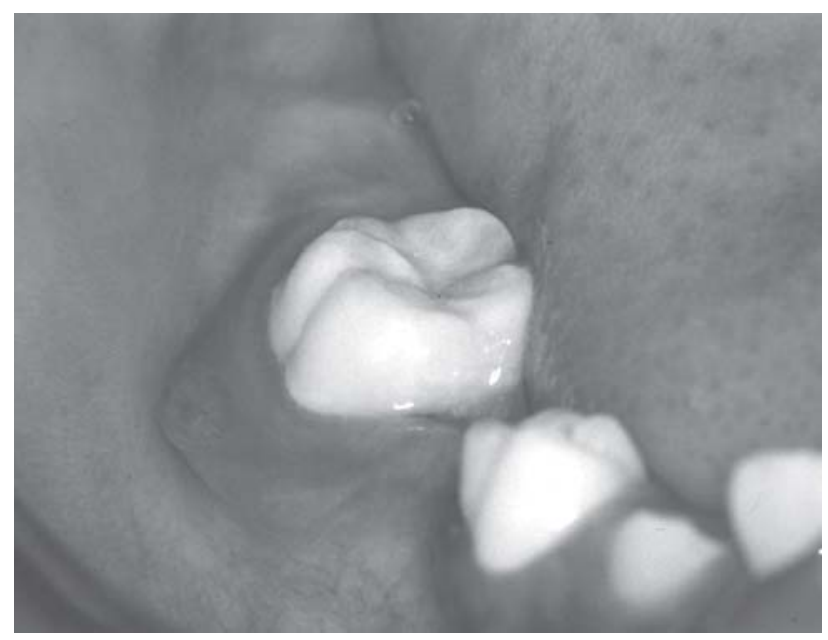

Figure 9- At 6-month recall, the presence of a fistula at buccal surface

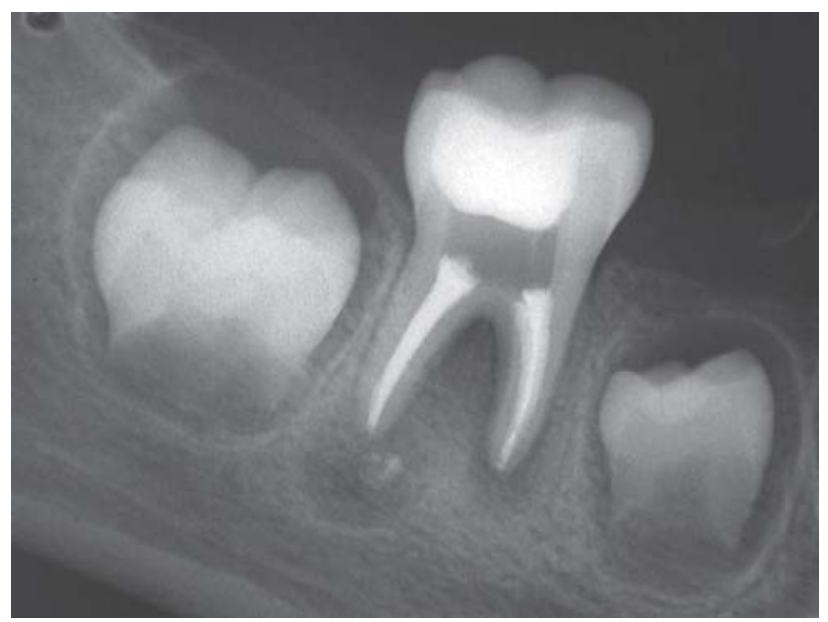

Figure 11- Endodontic treatment performed 
4- Cole BO, Welbury RR. The atraumatic restorative treatment (ART) technique: does it have a place in every day practice? SADJ. 2000; 56:321-6.

5- Ewoldsen N, Covey D, Lavin M. The physical and adhesive properties of dental cements used for Atraumatic restorative treatment. Spec Care Dent. 1997; 17:19-24.

6- Frencken JE, Makoni F, Sithole WD. ART restorations and glass ionomer sealants in Zimbabwe: survival after 3 years. Community Dent Oral Epidemiol. 1998;26:372-81.

7- Frencken JE, Makoni F, Sitholi WD. Atraumatic restorative treatment and glass-ionomer sealants in a school oral health programme in Zimbabwe: evaluation after 1 year. Caries Res. 1996; 30:428-33.

8- Frencken JE, Makoni F, Sitholi WD, Hackenitz E. Three-year survival of one-surface ART restorations and glass-ionomer sealants in a school oral health programme in Zimbabwe. Caries Res. 1999; 32:119-26.

9- Frencken JE, Pilot T, Songpaisan Y, Phantumvanit P. Atraumatic restorative treatment (ART): rationale, technique and development. J Public Hlth Dent. 1996;56:135-40.

10- Frencken JE, Pilot T, van Amerongen E, Phantumvanit P, Songpaisan Y. Manual for the Atraumatic Restorative Treatment approach to control dental caries. Groningen: WHO Collaborating Centre for Oral Health Services Research; 1997. p.1-88.

11- Frencken JE, Songpaisan Y, Phantumvanit P, Pilot T. An Atraumatic restorative treatment (ART) technique: evaluation after one year. Int Dent J. 1994;44:460-4.

12- Ho TF, Smales RJ, Fang DT. A 2-year clinical study of two glass ionomer cements used in the Atraumatic restorative treatment (ART) technique. Community Dent Oral Epidemiol. 1999;27:195-201.

13- Hosoya Y, García-Godoy F. Bonding mechanism of Ketac-Molar aplicap and Fuji IX to enamel and dentin. Amer J Dent. 1998;11:2359 .

14- Mallow PK, Durward CS, Klaipo M. Restoration of permanent teeth in young rural children in Cambodia using the Atraumatic restorative treatment (ART) technique and Fuji II glass ionomer cement. International J Paed Dent. 1998;8:35-40.

15- Mandari GJ, Frencken JE, van't Hof MA. Six-year success rates of occlusal amalgam and glass-ionomer restorations placed using three minimal intervention approaches. Caries Res. 2003;37:246-53.

16- Mickenautsch S, Rudolph MJ, Ogunbodede EO, Frencken JE. The impact of ART approach on the treatment profile in a mobile dental system (MDS) in South Africa. Int Dent J. 1999;49:132-8.

17- Mijör IA, Gordan VV. A review of Atraumatic restorative treatment (ART). Int Dent J. 1999;49:127-31.

18- Phantumvanit P, Songpaisan Y, Pilot T, Frencken JE. Atraumatic restorative treatment (ART): a three-year community field trial in Thailand - survival of one-surface restorations in permanent dentition. J Public Hlth Dent. 1996;56:141-5.

19- Smith AJ, Chimimba PD, Kalf-Scholte S, Bouma J. Clinical pilot study on new dental filling materials and preparation procedures en developing countries. Community Dent Oral Epidemiol. 1990; 18:309-12.

20- Souza EM, Cefaly DF, Terada RS, Rodrigues CC, Lima Navarro MF. Clinical evaluation of the ART technique using high density and resin-modified glass lonomer cements. Oral Hlth Prev Dent. 2003;1:201-7.
21- van Amerongen WE. Dental caries under glass ionomer restorations. J Public Hlth Dent. 1996;56:150-4.

22- Watson TF. Bonding glass-ionomer cements to tooth structures. In: Mijör IA, Davidsom CL. Advances in glass ionomer cements. Chicago: Quintessence Publishing; 1999. p 21-35.

23- Weerheijm KL, Groen HJ. The residual caries dilemma. Community Dent Oral Epidemiol. 1999;27:436-41.

24- Weerheijm KL, Soet JJ, van Amerongen WE, de Graaff J. The effect of glass-ionomer cement on carious dentine: an in vivo study. Caries Res. 1993;27:417-23.

25- WHO Oral Health. 1994 <http://www.who.int/aboutwho/en/ promoting/oral.htm>.

26- WHO Oral Health Activities (2002) <http://www.who.int/ncd/ orh/orh_act.htm>.

27- WHO/28 - 7 April 1994b Revolutionary new procedure for treating dental caries <http://www.who.int/archieves/inf-pr-1994/ pr94-28.htm>. 